\title{
Effect of Silkworm Pupae Compost on Soil N mineralization, Nutrient Uptake, Crop Yield and Plant Nutrient Contents of French Bean (Phaseolus vulgaris L.)
}

\author{
A.P. Heenkende and V.R.R. Parama ${ }^{1}$ \\ Department of Export Agriculture \\ Matale, Sri Lanka
}

\begin{abstract}
A field experiment was conducted during the period of December 2007 to March 2008 on a sandy clay loam soil in Bangalore, India to study the effect of silkworm pupae compost as a nutrient source for French bean. Four different mixtures of seri-compost were prepared using raw pupae wastes of silkworm and evaluated for soil $N$ mineralization, plant nutrient content, nutrient uptake and yield of French bean. Soil incubation and a field experiment was conducted using 11 treatment combinations containing different ratios of inorganic fertilizers, farm yard manure and seri-compost.
\end{abstract}

The $\mathrm{NH}_{4}{ }^{+}-\mathrm{N}$ release in soil increased rapidly up to 28 days after incubation (DAI) and thereafter, it decreased. At 0-28 days after incubation, the highest increase in $\mathrm{NH}_{4}{ }^{+}-\mathrm{N}$ was recorded in treatment $8(T 8)$ which contained 50\% N RDF (Recommended dose of fertilizer) $+50 \% \mathrm{~N}$ seri-compost 3(C3) prepared with silkworm pupae waste and $10 \%$ cowdung slurry (5.6 to $92.2 \mathrm{mg} \mathrm{kg}^{-1}$ ). The lowest increase was in treatment 5 (T5) in which $100 \% \mathrm{~N}$ supplied through Seri-compost 4 (C4) prepared with silkworm pupae waste with $10 \%$ cow dung slurry, 5\% rock phosphate and microbial inoculant (14 to $28 \mathrm{mg} \mathrm{kg}^{-1}$ ). At 0-21 days after incubation, the highest increase in $\mathrm{NO}_{3}^{-}-\mathrm{N}$ release was recorded in treatment 2 (T2); $100 \%$ $N$ through seri-compost $1(C 1)$ prepared with silk worm pupae waste and farm yard manure (16.8 to $112 \mathrm{mg} \mathrm{kg}^{-1}$ ) and lowest in treatment 4 (T4);100\% $\mathrm{N}$ through seri-compost 3 (C3) (50.4 to $92 \mathrm{mg} \mathrm{kg}^{-1}$ ). The $\mathrm{NO}_{3}^{-}-\mathrm{N}$ release in soil increased rapidly up to $21 \mathrm{DAI}$ and thereafter it decreased.

All the silkworm pupae compost treatments incorporated with 50\% N RDF improved yield and highest bean yield of $5793 \mathrm{~kg} \mathrm{ha} a^{-1}$ was in treatment 7 (T7) which contained $50 \% \mathrm{~N} \mathrm{RDF}$ $+50 \% N$ Seri-compost 2 . The highest $N, P$ and $K$ content of French bean plants at maturity was noticed in T6 (50\% N RDF + 50\% N silkworm pupae compost 1), T7 (50\% N RDF + $50 \% N$ seri-compost 2) and $T 3(100 \% N$ through Seri-compost 2) treatments respectively. Application of seri-compost increased available $\mathrm{N}_{2} \mathrm{P}_{2} \mathrm{O}_{5}$ and $\mathrm{K}_{2} \mathrm{O}$ status of the postharvest soil. Highest N, P and K uptake was recorded from 50\% N RDF with seri-compost 2 (T3), seri-compost 3(T8) and $100 \% \mathrm{~N}$ through seri-compost 3(T4) respectively. Therefore sericompost could be used to obtain higher yields of French bean than the recommended package of practices with inorganic fertilizer.

Department of Soil Science and Agricultural Chemistry, College of Agriculture, University of Agricultural Sciences, GKVK, Bangalore - 560065, India 


\section{INTRODUCTION}

Silkworm pupae are a major by product of the silk industry obtained after reeling. Most of the pupae are used as manure and a small proportion is used as a constituent of chick and fish feed (Mathur et al.,1998). The major difficulty in the utilization of spent silk worm pupae is that it cannot be stored for long periods as it has a bad odour (Yashoda et al., 2001). Dried silkworm pupae contain about $8 \%$ nitrogen. The crude protein extracted with $0.5 \%$ sodium hydroxide contains $12.22 \%$ nitrogen (Nagaraj and Basavanna, 1996). Silkworm pupae is used as a manure for mulberry in two different forms viz. raw pupae powder and deoiled pupae powder. Application of pupae powder resulted in significantly greater root and shoot weight, leaf yield and mineral contents of mulberry leaf (Anon, 1967).

Since the pupae contains high amount of nitrogen and protein, there is potential for the bio conversion of pupal waste to enriched compost and utilization as a nutrient source (Singhal et al., 2001). Any compost prepared, needs to be field evaluated to ascertain the influence on soil $\mathrm{N}$ mineralization, plant nutrient content, nutrient uptake and crop yield. Keeping this in view, the present investigation was carried out to study the effects of silk worm pupae compost (seri-compost) and fertilizer on soil $\mathrm{N}$ mineralization, plant nutrient content, nutrient uptake and yield of French bean.

\section{MATERIALS AND METHODS}

\section{Preparation of compost mixtures and treatment combinations}

Four different seri-compost mixtures (C1- raw pupae waste $50 \mathrm{~kg}+$ farmyard manure $50 \mathrm{~kg}$, $\mathrm{C} 2$ - raw pupae waste $50 \mathrm{~kg}+$ microbial inoculum $20 \mathrm{~kg}, \mathrm{C} 3$ - raw pupae waste $50 \mathrm{~kg}+10 \%$ cow dung slurry, C4- Raw pupae waste $50 \mathrm{~kg}+10 \%$ cowdung slurry + microbial inoculum $+5 \%$ Rock phosphate) were prepared after allowing the additive mixtures for 120 days for microbial decomposition (bio composting). Eleven fertilizer mixtures were prepared by mixing the prepared Seri-compost with inorganic fertilizers (Table 1) and evaluated at field conditions for soil $\mathrm{N}$ mineralization, plant nutrient content, nutrient uptake and yield of French bean.

\section{Soil incubation experiment}

An incubation study for a period of 60 days was conducted in the laboratory to study the nitrogen release pattern in soils applied with different seri-compost mixtures (T1-T11) using soils collected from the site of field experiment. Soil samples were analyzed by steam distillation technique for $\mathrm{NH}_{4}{ }^{+}-\mathrm{N}$ and $\mathrm{NO}_{3}{ }^{-}-\mathrm{N}$ after extracting with $2 \mathrm{M} \mathrm{KCl}$ at weekly intervals (Sparks, 1996). The data were analyzed using GLM procedure of SAS and Critical differences (CD) were used for comparison.

\section{Field experiment}

A field experiment was conducted at the Division of Horticulture, University of Agricultural Sciences, GKVK, Bangalore during the period of December 2007 to March 2008. The treatments (Table 1) were replicated three times and laid out in Randomized Complete Block Design. The French bean variety Selection 9 of was used for the study. Recommended fertilizer dosage (RDF) was 63:100:75 $\mathrm{kg} \mathrm{ha}^{-1}\left(\mathrm{~N}, \mathrm{P}_{2} \mathrm{O}_{5}, \mathrm{~K}_{2} \mathrm{O}\right)$. The yield components were recorded and $\mathrm{N}, \mathrm{P}$ and $\mathrm{K}$ contents of plants were analyzed at harvest by Micro-Kjeldahl and 
di-acid analysis (Piper, 1996) respectively. Available $\mathrm{N}$ of soil was extracted using alkaline potassium permanganate (Subbaiah and Asija, 1956), P by- Bray Method (Jackson, 1973) and $\mathrm{K}$ was extracted by ammonium acetate and determined using a Flame photometer (Stanford and English, 1949).

Table 1. Treatment details of the field experiment

\begin{tabular}{ll}
\hline Treatment & Composition of the mixture \\
\hline T1 & Inorganic RDF + Farmyard Manure $25 \mathrm{t} / \mathrm{ha}$ \\
$\mathrm{T} 2$ & $100 \% \mathrm{~N}$ through seri-compost $1(\mathrm{C} 1)$ \\
$\mathrm{T} 3$ & $100 \% \mathrm{~N}$ through seri-compost $2(\mathrm{C} 2)$ \\
$\mathrm{T} 4$ & $100 \% \mathrm{~N}$ through seri-compost $3(\mathrm{C} 3)$ \\
$\mathrm{T} 5$ & $100 \% \mathrm{~N}$ through seri-compost $4(\mathrm{C} 4)$ \\
$\mathrm{T} 6$ & $50 \% \mathrm{~N} \mathrm{RDF}+50 \% \mathrm{~N}$ seri-compost 1 \\
$\mathrm{~T} 7$ & $50 \% \mathrm{~N} \mathrm{RDF}+50 \% \mathrm{~N}$ seri-compost 2 \\
T8 & $50 \% \mathrm{~N} \mathrm{RDF}+50 \% \mathrm{~N}$ seri-compost 3 \\
$\mathrm{~T} 9$ & $50 \% \mathrm{~N} \mathrm{RDF}+50 \% \mathrm{~N}$ seri-compost 4 \\
T10 & $100 \% \mathrm{~N}$ through farmyard manure \\
T11 & $50 \% \mathrm{~N} \mathrm{RDF}+50 \% \mathrm{~N}$ farmyard manure \\
\hline
\end{tabular}

\section{RESULTS AND DISCUSSION}

\section{Soil incubation experiment}

The $\mathrm{NH}_{4}{ }^{+}-\mathrm{N}$ release in soil differed significantly at each sampling period (Table 2). The $\mathrm{NH}_{4}{ }^{+}-\mathrm{N}$ release in soil increased rapidly up to 28 days after incubation (DAI) and decreased thereafter. At 28 days after incubation, the highest increase in $\mathrm{NH}_{4}{ }^{+}-\mathrm{N}$ was recorded in $\mathrm{T} 8$ which contained 50\% N RDF $+50 \% \mathrm{~N}$ seri-compost $3\left(5.6\right.$ to $92.2 \mathrm{mg} \mathrm{kg}^{-1}$ ) and lowest in T5, which contained $100 \% \mathrm{~N}$ through seri-compost 4 (14 to $\left.28 \mathrm{mg} \mathrm{kg}^{-1}\right)$. At 60 DAI highest $\mathrm{NH}_{4}{ }^{+} \mathrm{N}$ release was also recorded in the Treatment 8 (T8). Among the treatments which contained only organic fertilizers, the use of $100 \% \mathrm{~N}$ through seri-compost 1 (T2) recorded the highest $\mathrm{NH}_{4}{ }^{+}-\mathrm{N}$ release between 7 to 28 DAI. However, combination of seri-compost with inorganic fertilizers recorded a higher $\mathrm{NH}_{4}{ }^{+} \mathrm{N}$ release compared to that of seri-compost along.

The $\mathrm{NO}_{3}{ }^{-} \mathrm{N}$ release in soil differed significantly among the treatments at each sampling period (Table 3). The $\mathrm{NO}_{3}{ }^{-} \mathrm{N}$ release in soil increased rapidly up to $21 \mathrm{DAI}$ and thereafter declined. However in $\mathrm{T} 1$ (recommended package of practice) $\mathrm{NO}_{3}^{-}-\mathrm{N}$ release in soil increased rapidly up to 28 DAI and thereafter declined. At 0-21 days after incubation, the highest increase in $\mathrm{NO}_{3}{ }^{-} \mathrm{N}$ release was recorded in treatment $100 \% \mathrm{~N}$ through Seri-compost 1 (T2) (16.8 to $112 \mathrm{mg} \mathrm{kg}^{-1}$ ) and the lowest in treatment that supplied $100 \% \mathrm{~N}$ through Seri Compost 3 (T4) (50.4 to $92 \mathrm{mg} \mathrm{kg}^{-1}$ ). Among the treatments which contained inorganic fertilizers, T8 $\left(50 \% \mathrm{~N} \mathrm{RDF}+50 \% \mathrm{~N}\right.$ seri-compost 3) recorded the highest increase of $\mathrm{NO}_{3}^{-}-$ 
$\mathrm{N}$ release (22.4 to $108 \mathrm{mg} \mathrm{kg}^{-1}$ ) between 0-21 DAI. seri-compost incorporated treatments (T2 to T9) has recorded a higher $\mathrm{NO}_{3}^{-}-\mathrm{N}$ release at the beginning of the incubation study than the other treatments.

Table 2. Release of $\mathrm{NH}_{4}{ }^{+}-\mathrm{N}\left(\mathrm{mg} \mathrm{kg}^{-1}\right)$ in soils incubated with silkworm pupae compost over time

\begin{tabular}{cccccccc}
\hline \multirow{2}{*}{ Treatments } & \multicolumn{7}{c}{ Days after Incubation } \\
\cline { 2 - 8 } & $\mathbf{0}$ & $\mathbf{7}$ & $\mathbf{1 4}$ & $\mathbf{2 1}$ & $\mathbf{2 8}$ & $\mathbf{4 5}$ & $\mathbf{6 0}$ \\
\hline $\mathbf{T}_{\mathbf{1}}$ & 8.40 & 33.60 & 36.40 & 39.40 & 40.20 & 28.00 & 20.00 \\
$\mathbf{T}_{\mathbf{2}}$ & 8.40 & 45.00 & 54.00 & 58.00 & 34.00 & 28.00 & 28.00 \\
$\mathbf{T}_{\mathbf{3}}$ & 2.80 & 28.00 & 34.00 & 36.00 & 38.00 & 42.00 & 24.00 \\
$\mathbf{T}_{\mathbf{4}}$ & 11.20 & 39.20 & 46.13 & 50.00 & 52.00 & 56.00 & 22.00 \\
$\mathbf{T}_{\mathbf{5}}$ & 14.00 & 16.00 & 21.00 & 28.00 & 21.00 & 20.00 & 18.00 \\
$\mathbf{T}_{\mathbf{6}}$ & 16.80 & 31.00 & 39.20 & 42.00 & 56.00 & 28.00 & 12.00 \\
$\mathbf{T}_{\mathbf{7}}$ & 19.60 & 36.40 & 28.00 & 42.00 & 58.00 & 24.00 & 22.00 \\
$\mathbf{T}_{\mathbf{8}}$ & 5.60 & 45.00 & 67.20 & 80.00 & 92.20 & 36.40 & 28.00 \\
$\mathbf{T}_{\mathbf{9}}$ & 16.00 & 28.00 & 28.00 & 32.00 & 28.00 & 20.00 & 13.00 \\
$\mathbf{T}_{\mathbf{1 0}}$ & 16.80 & 28.00 & 28.00 & 32.00 & 28.00 & 20.00 & 13.00 \\
$\mathbf{T}_{\mathbf{1 1}}$ & 14.00 & 22.00 & 22.00 & 42.00 & 26.00 & 20.00 & 13.00 \\
\hline $\mathrm{SE}$ & 0.788 & 0.981 & 0.498 & 0.786 & 1.18 & 1.03 & 1.34 \\
\hline
\end{tabular}

Table 3. Release of $\mathrm{NO}_{3}{ }^{-}-\mathrm{N}\left(\mathrm{mg} \mathrm{kg}^{-1}\right)$ in soils incubated with seri-pupae compost over time

\begin{tabular}{cccccccc}
\hline \multirow{2}{*}{ Treatments } & \multicolumn{7}{c}{ Days After Incubation } \\
\cline { 2 - 8 } & $\mathbf{0}$ & $\mathbf{7}$ & $\mathbf{1 4}$ & $\mathbf{2 1}$ & $\mathbf{2 8}$ & $\mathbf{4 5}$ & $\mathbf{6 0}$ \\
\hline $\mathrm{T}_{1}$ & 11.20 & 28.00 & 45.00 & 56.00 & 87.00 & 64.00 & 43.00 \\
$\mathrm{~T}_{2}$ & 16.80 & 31.00 & 45.00 & 112.00 & 56.00 & 47.00 & 26.0 \\
$\mathrm{~T}_{3}$ & 25.20 & 28.00 & 33.60 & 87.00 & 72.00 & 38.00 & 20.00 \\
$\mathrm{~T}_{4}$ & 50.40 & 39.20 & 42.00 & 92.00 & 80.00 & 67.00 & 54.00 \\
$\mathrm{~T}_{5}$ & 50.40 & 28.00 & 39.00 & 89.00 & 78.00 & 64.00 & 48.00 \\
$\mathrm{~T}_{6}$ & 22.40 & 31.00 & 38.00 & 82.00 & 68.00 & 54.00 & 48.00 \\
$\mathrm{~T}_{7}$ & 33.60 & 36.40 & 37.00 & 78.00 & 75.00 & 58.00 & 41.00 \\
$\mathrm{~T}_{8}$ & 22.40 & 33.60 & 42.00 & 108.00 & 86.60 & 82.00 & 46.00 \\
$\mathrm{~T}_{9}$ & 22.40 & 28.00 & 38.00 & 92.00 & 78.00 & 70.00 & 38.00 \\
$\mathrm{~T}_{10}$ & 14.00 & 28.00 & 32.00 & 68.00 & 43.00 & 48.00 & 28.00 \\
$\mathrm{~T}_{11}$ & 8.40 & 28.00 & 32.00 & 52.00 & 70.00 & 67.00 & 34.00 \\
\hline $\mathrm{SE} \%$ & 1.19 & 0.904 & 1.10 & 1.04 & 0.467 & 0.504 & 1.39 \\
\hline
\end{tabular}

\section{Field experiment}

The soil texture of the experimental site was sandy clay loam. The soil was acidic to neutral (6.75) with $0.12 \mathrm{dSm}^{-1}$ Electrical Conductivity (EC). The soil was low in organic carbon content $\left(4.9 \mathrm{~g} \mathrm{~kg}^{-1}\right)$, medium available $\mathrm{N}$ content $\left(306 \mathrm{~kg} \mathrm{ha}^{-1}\right)$ medium available $\mathrm{P}_{2} \mathrm{O}_{5}(25.37$ $\left.\mathrm{kg} \mathrm{ha}^{-1}\right)$ and high in available $\mathrm{K}_{2} \mathrm{O}\left(137.32 \mathrm{~kg} \mathrm{ha}^{-1}\right)$. The DTPA extractable $\mathrm{Zn}, \mathrm{Cu}, \mathrm{Fe}, \mathrm{Mn}$ were $1.07,1.25,13.42$ and $10.42 \mathrm{ppm}$, respectively. The CEC of the soil was $11.37 \mathrm{c} \mathrm{mol}$ $(\mathrm{p}+) \mathrm{kg}^{-1}$. 
There was a significant difference in available $\mathrm{N}$ content of the soil as affected by the treatments (Table 4). The residual $\mathrm{N}$ content had reduced in all the plots compared to initial value $(306 \mathrm{mg} / \mathrm{kg})$. The treatment $8(50 \% \mathrm{~N} \mathrm{RDF}+50 \% \mathrm{~N}$ seri-compost 3) recorded the highest available residual $\mathrm{N}$ among the silkworm compost treatments and the lowest available $\mathrm{N}$ content was in treatment $\mathrm{T} 1(100 \% \mathrm{RDF}+25 \mathrm{t} / \mathrm{ha} \mathrm{FYM})$. The variations could be due to their different decomposition rates.

Table 4. Effect of pupae compost on residual nutrient status of soil, nutrient uptake and plant nutrient content of French bean

\begin{tabular}{lccccccccc}
\hline \multirow{2}{*}{ Treatment } & \multicolumn{2}{l}{$\begin{array}{l}\text { Residual nutrient } \\
\text { status of soils }\left(\mathbf{k g ~ h a}^{-\mathbf{1}}\right)\end{array}$} & \multicolumn{3}{c}{$\begin{array}{c}\text { Nutrient uptake } \\
\left.\mathbf{( k g ~ h a ~}^{-1}\right)\end{array}$} & \multicolumn{3}{c}{$\begin{array}{c}\text { Plant nutrient } \\
\text { content }\end{array}$} \\
\cline { 2 - 10 } & $\mathrm{N}$ & $\mathrm{P}$ & $\mathrm{K}$ & $\mathrm{N}$ & $\mathrm{P}$ & $\mathrm{K}$ & $\mathrm{N}$ & $\mathrm{P}$ & $\mathrm{K}$ \\
\hline T1 & 169.77 & 23.36 & 136.21 & 135.87 & 13.41 & 74.39 & 1.68 & 0.10 & 1.79 \\
T2 & 159.26 & 27.36 & 142.00 & 102.85 & 13.11 & 68.24 & 2.62 & 0.13 & 1.79 \\
T3 & 176.37 & 28.36 & 144.00 & 123.94 & 12.96 & 58.07 & 2.90 & 0.10 & 1.28 \\
T4 & 192.47 & 29.36 & 143.00 & 161.79 & 13.93 & 99.28 & 2.50 & 0.11 & 2.20 \\
T5 & 187.86 & 30.46 & 144.00 & 134.83 & 14.59 & 74.53 & 2.39 & 0.13 & 1.69 \\
T6 & 206.13 & 26.52 & 145.00 & 96.82 & 14.62 & 59.35 & 2.08 & 0.16 & 1.59 \\
T7 & 246.53 & 29.42 & 146.21 & 151.02 & 16.46 & 88.99 & 2.93 & 0.13 & 2.03 \\
T8 & 290.56 & 32.36 & 149.37 & 171.19 & 14.19 & 92.09 & 3.32 & 0.10 & 1.69 \\
T9 & 256.21 & 30.32 & 144.32 & 131.35 & 14.16 & 85.51 & 2.18 & 0.13 & 1.89 \\
T10 & 224.31 & 31.47 & 139.00 & 118.74 & 12.97 & 75.99 & 2.25 & 0.10 & 1.89 \\
T11 & 236.21 & 27.56 & 141.00 & 143.36 & 13.86 & 73.97 & 2.92 & 0.11 & 1.59 \\
& & & & & & & & & \\
SE & 4.36 & 2.34 & 2.53 & 0.60 & 0.47 & 0.04 & 0.04 & 0.01 & 0.02 \\
\hline
\end{tabular}

There was also a significant difference in available $\mathrm{P}_{2} \mathrm{O}_{5}$ and $\mathrm{K}_{2} \mathrm{O}$ content of the soil (Table 4). The residual $\mathrm{P}_{2} \mathrm{O}_{5}$ content had reduced in all the plots compared to initial value $(25.37 \mathrm{mg}$ $\left.\mathrm{kg}^{-1}\right)$. The treatment $8(50 \% \mathrm{~N} \mathrm{RDF}+50 \% \mathrm{~N}$ seri-compost 3) recorded highest available residual $\mathrm{P}_{2} \mathrm{O}_{5}$ and $\mathrm{K}_{2} \mathrm{O}$ among all the Seri-compost treatments and the lowest available $\mathrm{P}_{2} \mathrm{O}_{5}$ and $\mathrm{K}_{2} \mathrm{O}$ content was at treatment $\mathrm{T} 1(100 \% \mathrm{RDF}+\mathrm{FYM} 25 \mathrm{t} / \mathrm{ha})$. This variations could also be due to their different decomposition rates. All the seri-compost applied plots recorded higher $\mathrm{N}$ content compared to that of $\mathrm{T} 1$. The highest $\mathrm{N}$ uptake as well as $\mathrm{N}$ content $(3.32 \%)$ was also recorded in the T8. The increase in $\mathrm{N}$ content of French bean due to compost treatments may be attributed to the release of $\mathrm{N}$ from both organic forms and chemical fertilizers. Similar increase in N content and uptake has been reported by Kropisz and Russel (1978) with municipal waste compost. They reported that the combined application of fertilizer nitrogen, phosphorus and potassium and municipal waste compost increased the nitrogen content compared to the application of mineral fertilizers only.

There was a significant increase in the $\mathrm{P}$ content of plants due to enriched seri-compost treatments compared to inorganic fertilizer treated and FYM treated plots. Significant differences in $\mathrm{P}$ uptake was observed among treatments and highest $\mathrm{P}$ uptake was recorded in $\mathrm{T} 7$ which received $50 \% \mathrm{~N}$ RDF+ 50\% N seri-compost 2. The increase in $\mathrm{P}$ content could be attributed to the increased utilization of native $\mathrm{P}$ and/or due to enhanced dissolution of $\mathrm{P}$ by organic acids produced during the decomposition of organic matter. Mishra et al., (1982) also reported that addition of high doses of garbage compost increased the amount of $\mathrm{P}$ in plants. The $\mathrm{K}$ uptake also differed significantly among treatments and the highest $\mathrm{K}$ uptake was recorded in T4 which received $100 \% \mathrm{~N}$ through Seri-compost 3 . The highest K content 
of plants was also recorded in this treatment. The high $\mathrm{K}$ content of French bean plants grown with Seri-compost may be due to the release of $\mathrm{K}$ from organic manures or due to the action of organic acids which promote the release of mineral bound insoluble $\mathrm{K}$.

There were significant differences among treatments on French bean yield (Table 5). The highest french bean yield $\left(5793 \mathrm{~kg} \mathrm{ha}^{-1}\right)$ was recorded in $\mathrm{T} 7$ which received 50 per cent $\mathrm{N}$ $\mathrm{RDF}+50 \% \mathrm{~N}$ seri-compost 2 while the lowest French bean yield $\left(3263 \mathrm{~kg} \mathrm{ha}^{-1}\right)$ was recorded in treatment T2 which was $100 \% \mathrm{~N}$ through Seri Compost 1 (C1). Treatment T8 $(50 \% \mathrm{~N} \mathrm{RDF}+50 \% \mathrm{~N}$ Seri Compost 3$)$ also recorded yield which was not significantly different to that of $\mathrm{T} 7\left(5642 \mathrm{~kg} \mathrm{ha}^{-1}\right)$.

Table 5. Effect of seri-compost on French bean yield

\begin{tabular}{cc}
\hline Treatment & $\begin{array}{c}\text { Fresh bean yield } \\
\text { kg ha }\end{array}$ \\
\hline $\mathrm{T}_{1}$ & 4223 \\
$\mathrm{~T}_{2}$ & 3263 \\
$\mathrm{~T}_{3}$ & 3490 \\
$\mathrm{~T}_{4}$ & 4034 \\
$\mathrm{~T}_{5}$ & 3505 \\
$\mathrm{~T}_{6}$ & 3809 \\
$\mathrm{~T}_{7}$ & 5793 \\
$\mathrm{~T}_{8}$ & 5642 \\
$\mathrm{~T}_{9}$ & 4104 \\
$\mathrm{~T}_{10}$ & 3548 \\
$\mathrm{~T}_{11}$ & 5575 \\
$\mathrm{SE}$ & \\
$\mathrm{SE}$
\end{tabular}

Seri-compost integrated with inorganic $\mathrm{N}$ resulted in a higher bean yield over the recommended package of practice and integrated treatments with FYM. A similar experiment was conducted by Chavan (1997) who suggested that deoiled pupae could be used in place of chemical fertilizer along with the FYM to obtain the equivalent yield of French bean, as with that of FYM+ chemical fertilizers. It was stated that on the basis of current prices of various inputs use of deoiled pupae powder with FYM was economical than chemical fertilizer with FYM.

\section{CONCLUSION}

A Field experiment conducted to evaluate the silkworm pupae compost (Seri-compost) on French bean yield showed that all the Seri-compost treatment incorporated with 50\% N RDF performed better than other treatments. However, the highest French bean yield ( $5793 \mathrm{~kg} \mathrm{ha}$ ${ }^{1}$ ) was recorded in treatment which received 50\% N RDF $+50 \% \mathrm{~N}$ silkworm compost 2. Therefore, silkworm pupae compost could be used s a compost to obtain comparable yields to that obtained with inorganic fertilizers. 


\section{ACKNOWLEDGEMENTS}

The author wishes to acknowledge CARP (Sri Lanka Council for Agricultural Research Policy) Sri Lanka for financial assistance to pursue the Ph.D. degree programme in India under ICAR (Indian Council of Agriculture Research) - CARP programme. The author also thanks Dept. of Export Agriculture for the arrangements of the post graduate programme and for granting study leave.

\section{REFERENCES}

Anonymous (1967), Manurial value of silkworm pupae (Bombyx mori. L.) Annual report., CSR\&TI, Mysore, India, PP. 109-118.

Chavan, S.S., (1997), Influence of mulberry varieties on pupal oil yield of different breeds of Bomyx mori L. and utility of pupae. M.Sc. (Seri.) Thesis, Univ. Agril. Sci., Bangalore. India.

Jackson , M.L., (1973), Soil chemical analysis. Prentice Hall, New Delhi, pp. 1-485.

Kropisz, A. and Russel, S., (1978), Effect of fertilization of light loamy soil with the Dao compost on microflora as well as on yield and chemical compositai of liettuce and spinod. Rocz. Nauk Rol. Ser., 103(1): 20-37.

Mathur, S.K., Mukhopadhyyay, B.K. and Gangoli, R. (1998). Utilization of by products of mulberry silkworm, Indian Silk, 27(11):38-40.

Mishra, M.M., Kapoor, K.K. and Yadav, K.S., (1982), Effect of compost enriched with MRP on crop yield. Indian J. Agric. Sci., 52(10): 674-678.

Nagaraj, G. and Basavanna, H.M., (1996). Proteins from silkworm pupae. Silkworm Info. Bull., 1(1):29-30.

Piper, C.S. (1996), Soil and plant analysis, Hand pub., Bombay, India.

Singhal, B.K., Dhara, K., Tripathy, P.M., Gadry, S.M., Bindroo, B.B. and Ashan, M.M. (2001). Medicinal utilities of mulberry and non mulberry food plants of the silkworm. Recent progress in medicinal plants. Research periodicals and book publishing house, Texas.

Sparks, D.L., (1996), Methods of soil analysis, Part 3, Chemical methods, SSSA, book series: 5, publishes Madison, WI.

Stanford, P. and English, W.L., (1949), Use of flame photometer is rapid soil tests of potassium and calcium, J. Envt. Quality., 21: 635-642.

Subbaiah, B.V. and Asija, G.L., (1956), A rapid procedure for the estimation of the available nitrogen in soil. Curr. Sci., 25: 259-260.

Yashoda, K.P., Sachindra, N.M., Rao, D.N. and Mahendrakar, N.S., (2001). Changes in microbial population during fermentation of silkworm pupae. Sericologica, 41(2): 253-261 